SUPPORTING INFORMATION

\title{
Cooperativity of the N- and C-terminal Domains of Insulin-like Growth Factor Binding Protein-2 (IGFBP-2) in IGF Binding
}

\author{
Zhihe Kuang, ${ }^{\ddagger} \S$ Shenggen Yao, ${ }^{\ddagger}$ Kerrie A. McNeil, ${ }^{\S}$ Julian A. Thompson, ${ }^{\|}$Leon A. Bach, \\ Briony E. Forbes, ${ }^{\S}$ John C. Wallace, ${ }^{\S}$ and Raymond S. Norton ${ }^{*} \neq$
}

The Walter and Eliza Hall Institute of Medical Research, 1G Royal Parade, Parkville 3050 Australia, School of Molecular and Biomedical Science, The University of Adelaide, Adelaide 5005 Australia, and Department of Medicine, Monash University and Department of Endocrinology and Diabetes, Alfred Hospital, Melbourne 3004 Australia

* To whom correspondence should be addressed. ray.norton@wehi.edu.au. FAX: +61 39345 2686. Phone +61393452306. 

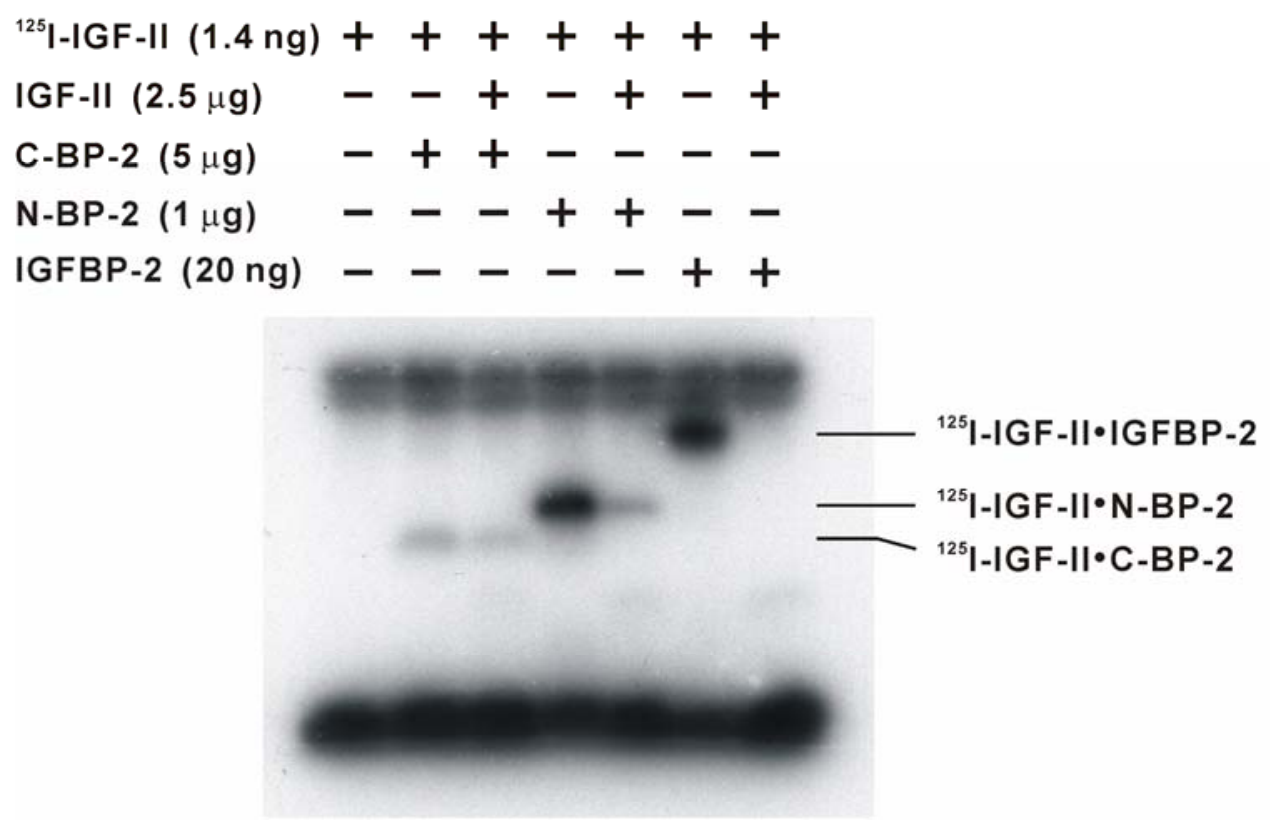

Figure S1. Affinity cross-linking of C-BP-2, N-BP-2, and IGFBP-2 to IGF-II

Binding of C-BP-2, N-BP-2, and IGFBP-2 to IGF-II was demonstrated by affinity cross-linking of these proteins to ${ }^{125}$ I-labelled IGF-II. C-BP-2, N-BP-2, or IGFBP-2 were incubated with ${ }^{125}$ I-IGF-II (200,000 cpm), with and without excess unlabelled IGF-II, at $4{ }^{\circ} \mathrm{C}$ overnight in $40 \mu \mathrm{L}$ of PBS. Disuccinimidyl suberate was then used to cross-link the interacting proteins. Samples were separated on SDS polyacrylamide gel, followed by autoradiography. 

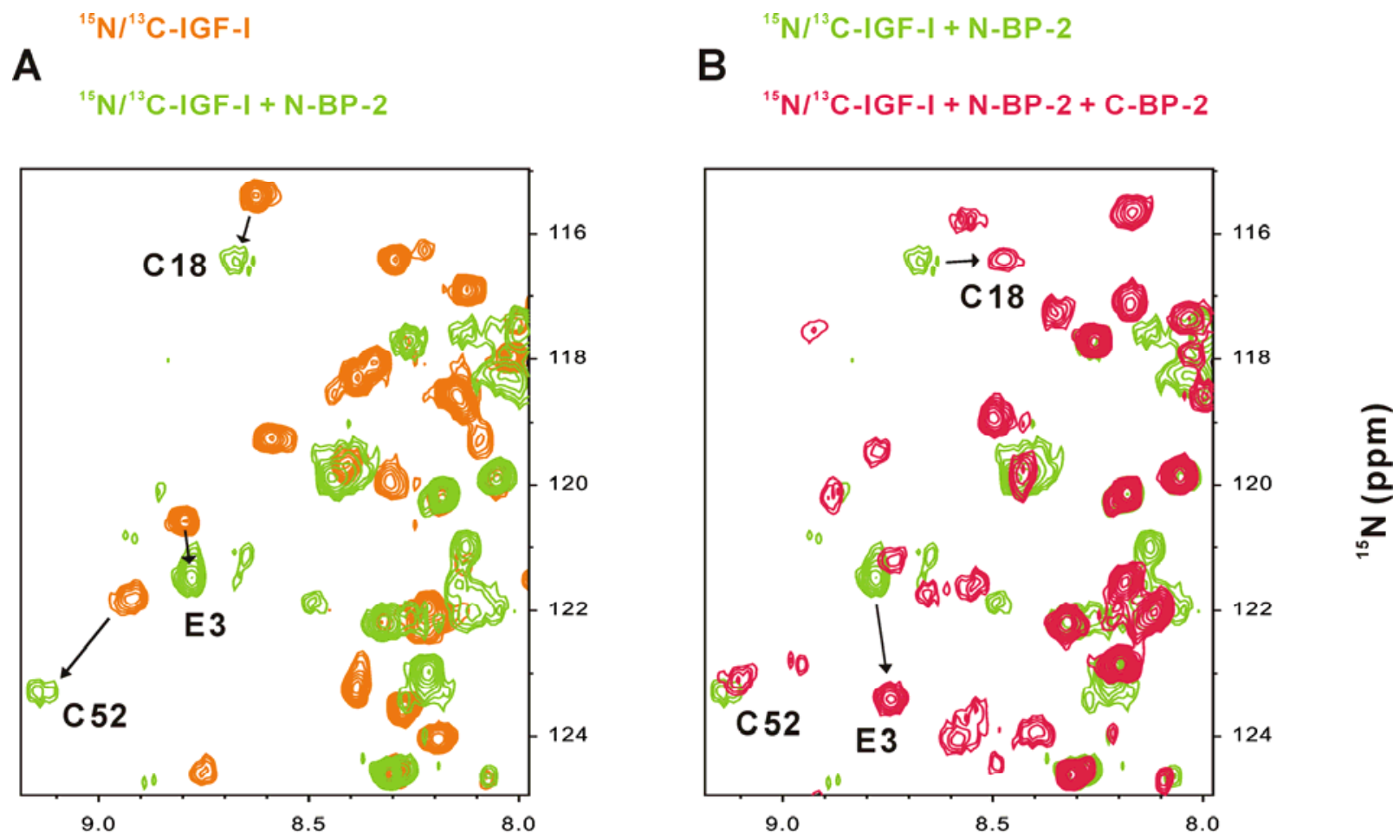

\section{${ }^{1} H(p p m)$}

Figure S2. Expanded views of selected regions of Figure $3 \mathrm{~A}$ and $3 \mathrm{~B}$.

(A) Overlay of ${ }^{1} \mathrm{H}_{-}{ }^{15} \mathrm{~N}$ HSQC spectra of $0.05 \mathrm{mM}{ }^{15} \mathrm{~N} /{ }^{13} \mathrm{C}$-labelled IGF-I in the absence (orange) and presence (green) of unlabelled N-BP-2 at IGF-I:N-BP-2 molar ratio of 1:1.5 at pH 6.0. (B) Overlay of ${ }^{1} \mathrm{H}_{-}{ }^{15} \mathrm{~N}$ HSQC spectra of $0.05 \mathrm{mM}{ }^{15} \mathrm{~N} /{ }^{13} \mathrm{C}$-labelled IGF-I in presence of N-BP-2 alone (green) and of N-BP-2 plus C-BP-2 (red, at IGF-I:N-BP-2:C-BP-2 molar ratio of 1:1.5:1.5) at pH 6.0. Selective ${ }^{1} \mathrm{H}-{ }^{15} \mathrm{~N}$ cross-peaks are labelled. Samples were in $95 \% \mathrm{H}_{2} \mathrm{O} / 5 \%{ }^{2} \mathrm{H}_{2} \mathrm{O}$ containing 10 $\mathrm{mM}$ sodium acetate, $150 \mathrm{mM} \mathrm{NaCl}$, and $0.02 \%(\mathrm{w} / \mathrm{v})$ sodium azide. Spectra were recorded at 500 $\mathrm{MHz}$ and $37^{\circ} \mathrm{C}$. 
A

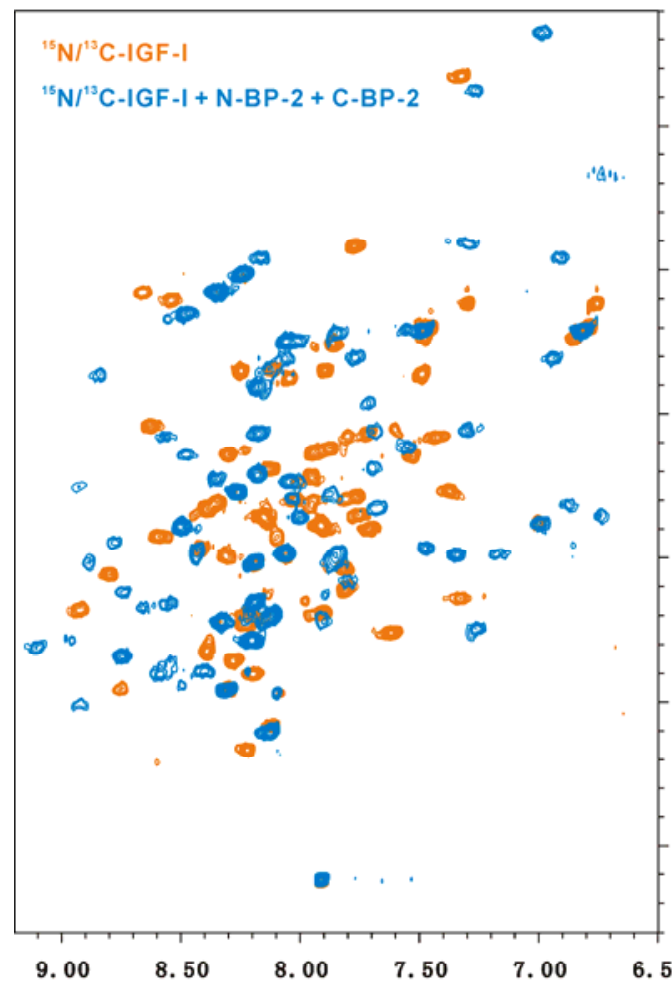

B Carrick, et al. 2005
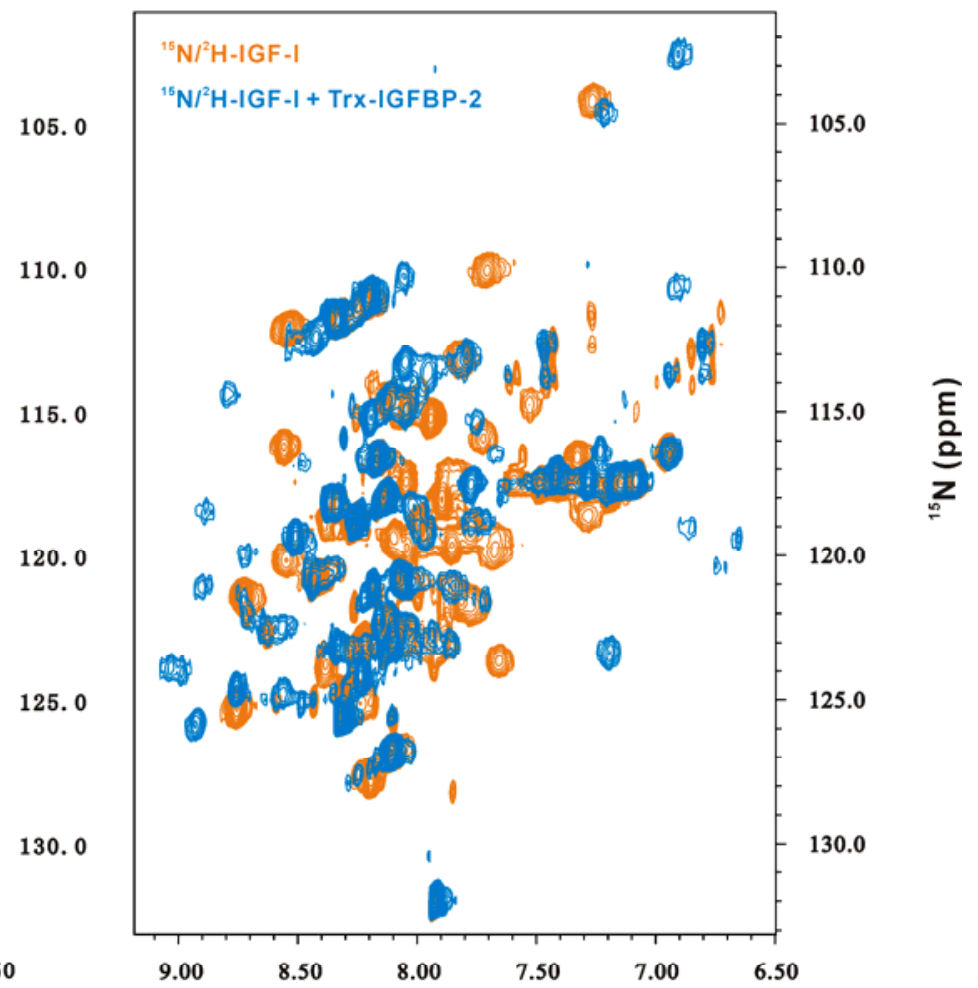

${ }^{1} \mathrm{H}(\mathrm{ppm})$

Figure S3. Comparison of ${ }^{1} \mathrm{H}-{ }^{15} \mathrm{~N}-\mathrm{HSQC}$ spectra of IGF-I in the IGF-I·N-BP-2·C-BP-2 ternary complex and the IGF-I-IGFBP-2 complex

Spectra in (A) were recorded on $0.05 \mathrm{mM}{ }^{15} \mathrm{~N} /{ }^{13} \mathrm{C}$-labelled IGF-I samples at $\mathrm{pH} 6.0,37{ }^{\circ} \mathrm{C}$ and $500 \mathrm{MHz}$ using a cryoprobe. (B) was modified from Figure 4A of Carrick et al (38). Spectra in (B) were ${ }^{1} \mathrm{H}_{-}{ }^{15} \mathrm{~N}$ TROSY spectra, recorded on $0.5 \mathrm{mM}{ }^{15} \mathrm{~N} /{ }^{2} \mathrm{H}-$ IGF-I samples at $\mathrm{pH} 4.8-5.1,37^{\circ} \mathrm{C}$ and $600 \mathrm{MHz}$ (38). IGFBP-2 was in the thioredoxin fusion protein form (38). 


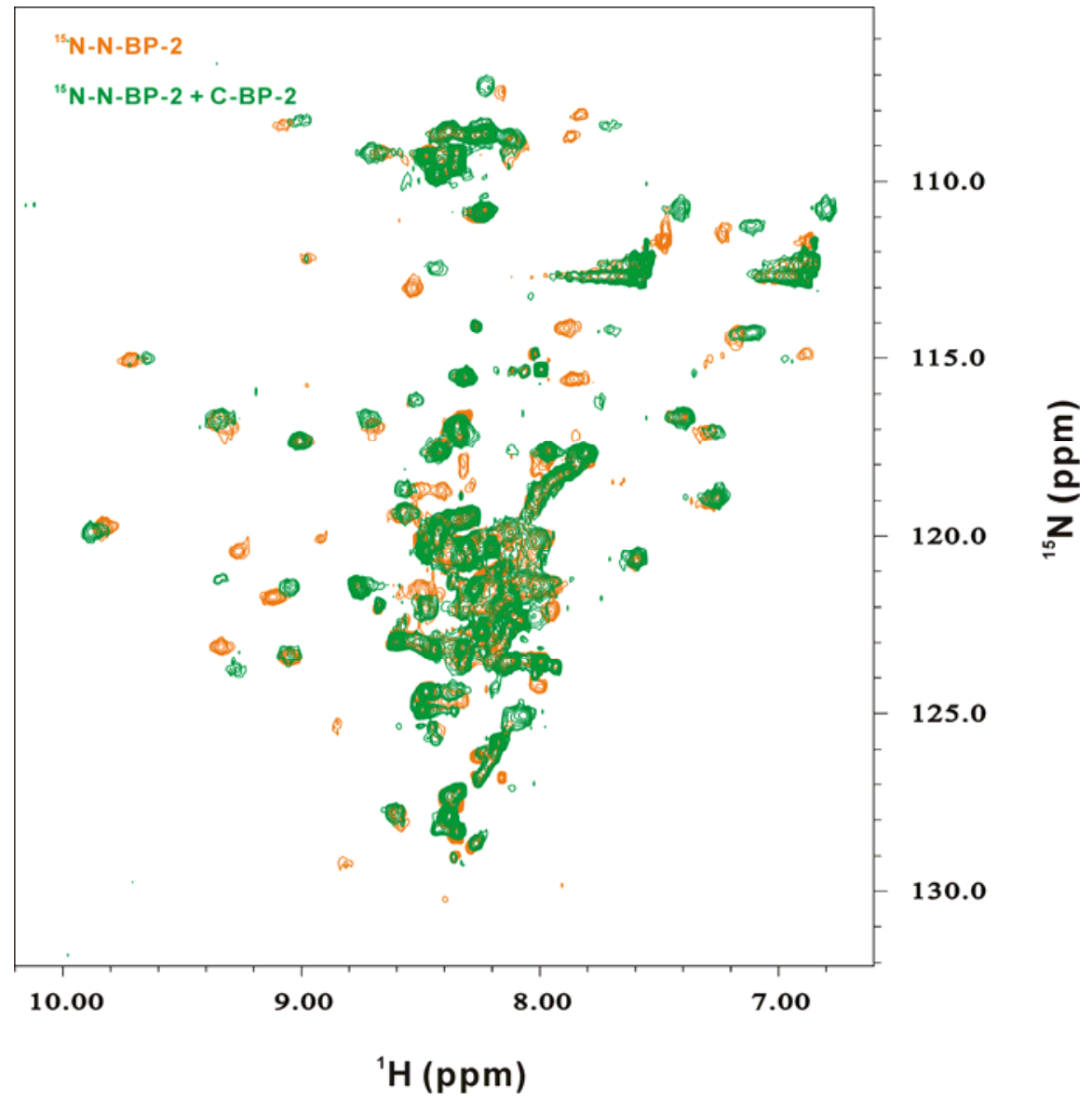

Figure S4. Overlay of ${ }^{1} \mathrm{H}-{ }^{15} \mathrm{~N}$ HSQC spectra of ${ }^{15} \mathrm{~N}$-labelled N-BP-2 in the absence (orange) and presence (green) of C-BP-2.

Overlay of ${ }^{1} \mathrm{H}^{15} \mathrm{~N}$ HSQC spectra of $0.07 \mathrm{mM}{ }^{15} \mathrm{~N}$-labelled N-BP-2 in the absence and presence of unlabelled C-BP-2 at N-BP-2:C-BP-2 molar ratios of 1:1.5. Samples were in $95 \% \mathrm{H}_{2} \mathrm{O} / 5 \%{ }^{2} \mathrm{H}_{2} \mathrm{O}$ containing $10 \mathrm{mM}$ sodium acetate and $0.02 \%(\mathrm{w} / \mathrm{v})$ sodium azide at $\mathrm{pH}$ 7.0. Spectra were recorded at $500 \mathrm{MHz}$ and $25{ }^{\circ} \mathrm{C}$, with a data matrix size of $2048 \times 128$ and 128 scans per $t 1$ increment. The spectral widths were $12.0 \mathrm{ppm}$ for ${ }^{1} \mathrm{H}$ and $35.0 \mathrm{ppm}$ for ${ }^{15} \mathrm{~N}$. Carrier frequencies were $4.7 \mathrm{ppm}$ for ${ }^{1} \mathrm{H}$ and $118 \mathrm{ppm}$ for ${ }^{15} \mathrm{~N}$. The converse experiment, addition of unlabelled N-BP-2 to ${ }^{15} \mathrm{~N}$-labelled C-BP-2, is shown in Figure 4A in the main text. 


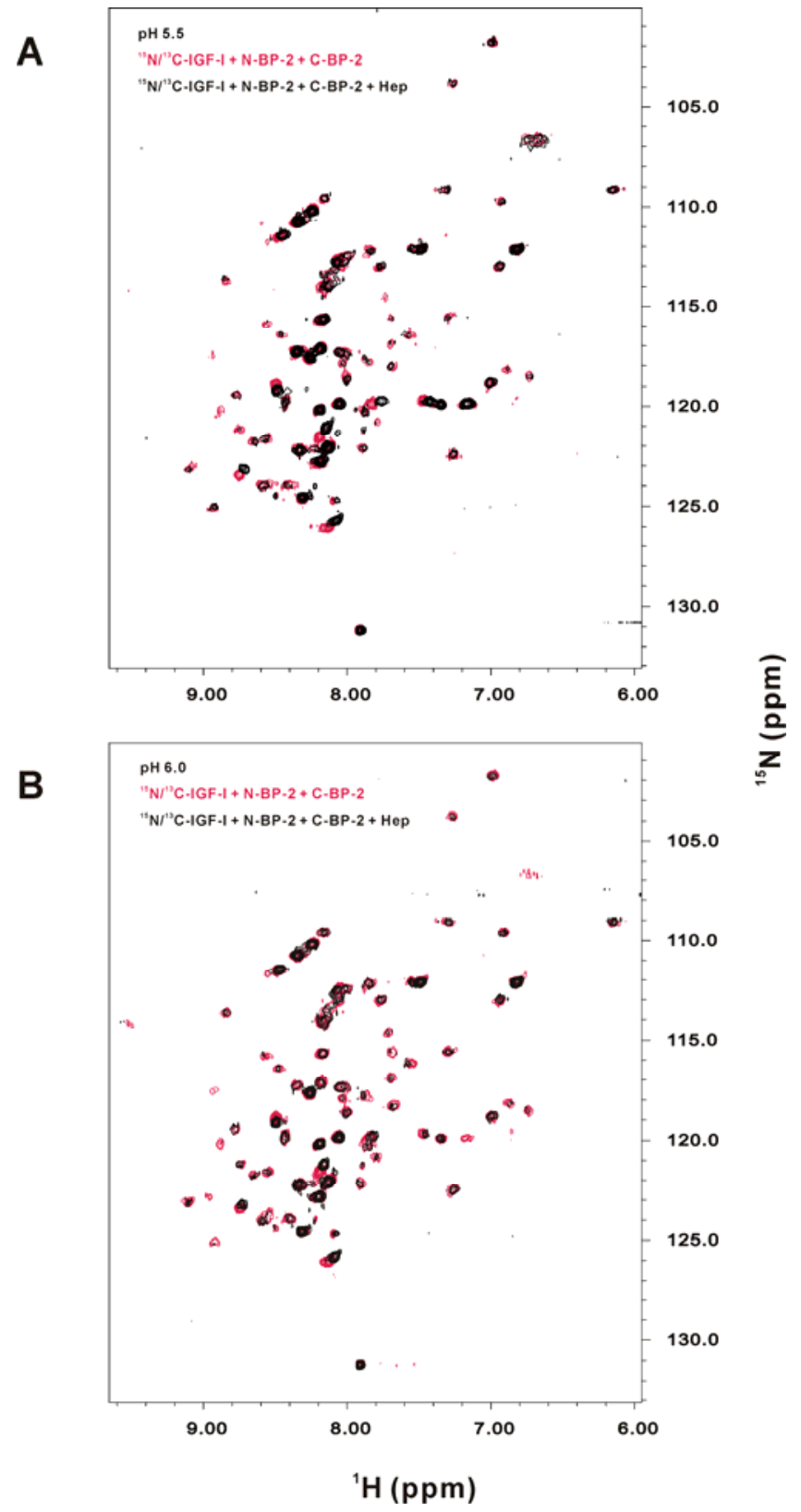

Figure S5. Heparin binding by the IGF-I·N-BP-2·C-BP-2 ternary complex

Overlay of ${ }^{1} \mathrm{H}_{-}{ }^{15} \mathrm{~N}$ HSQC spectra of $0.05 \mathrm{mM}{ }^{15} \mathrm{~N} /{ }^{13} \mathrm{C}$-labelled IGF-I in the IGF-I.N-BP-2.C-BP-2 ternary complex, and in the absence (red) and presence (black) of $2.0 \mathrm{mM}$ low molecular weight heparin at $\mathrm{pH} 5.5$ (A) and 6.0 (B). The samples were in $95 \% \mathrm{H}_{2} \mathrm{O} / 5 \%{ }^{2} \mathrm{H}_{2} \mathrm{O}$ containing $10 \mathrm{mM}$ sodium acetate, $150 \mathrm{mM} \mathrm{NaCl}$, and $0.02 \%(\mathrm{w} / \mathrm{v})$ sodium azide. Spectra were recorded at 500 $\mathrm{MHz}$ and $37^{\circ} \mathrm{C}$. These are the spectra presented in Figure 5, but with all peaks shown. 

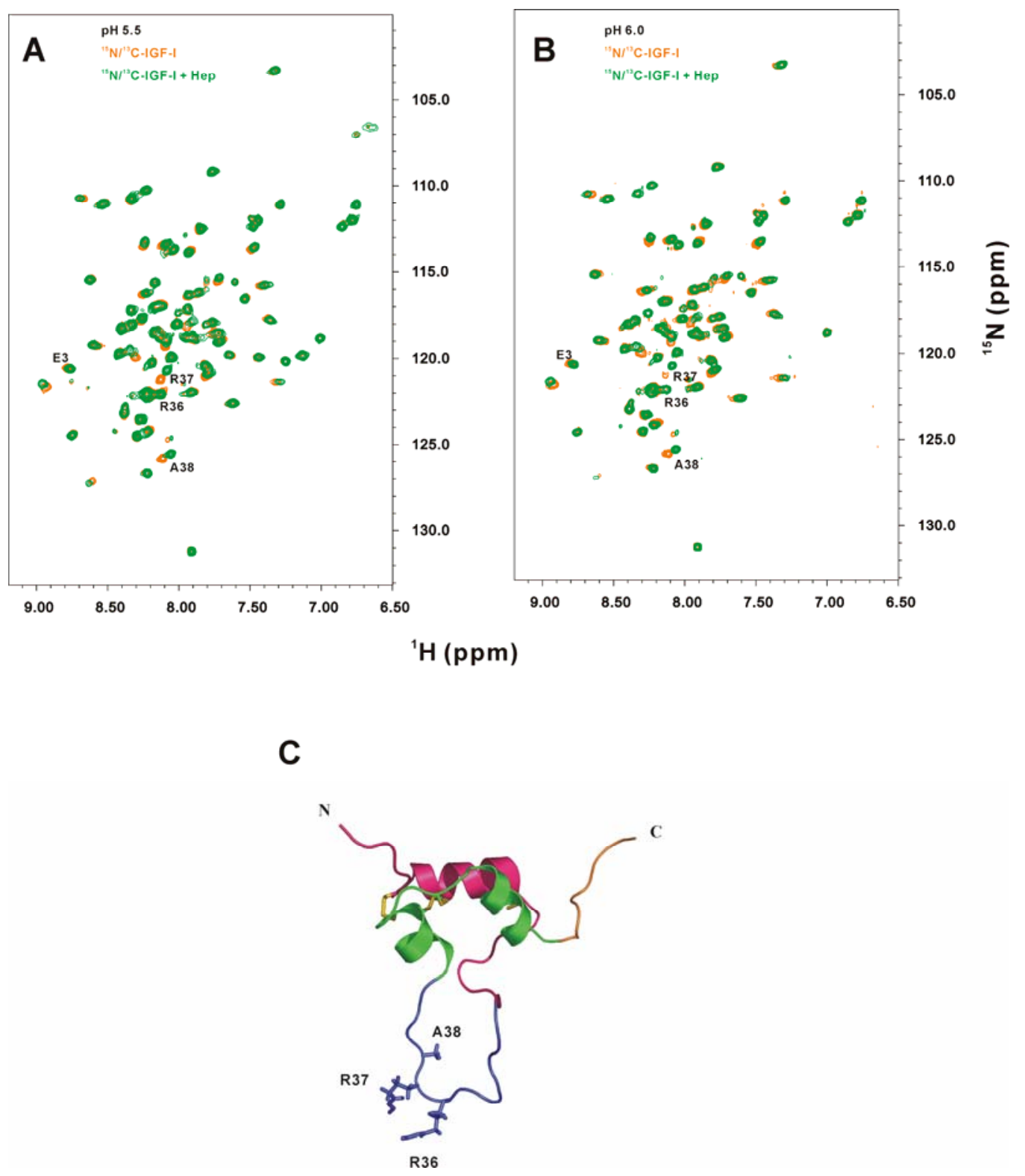

Figure S6. ${ }^{1} \mathrm{H}-{ }^{15} \mathrm{~N}$ HSQC spectra of ${ }^{15} \mathrm{~N} /{ }^{13} \mathrm{C}$-labelled IGF-I in the absence and presence of heparin

(A and B) Overlay of ${ }^{1} \mathrm{H}-{ }^{15} \mathrm{~N}$ HSQC spectra of $0.05 \mathrm{mM}{ }^{15} \mathrm{~N} /{ }^{13} \mathrm{C}$-labelled IGF-I in the absence (orange) and presence (green) of $2.0 \mathrm{mM}$ low molecular weight heparin. The samples were in $95 \% \mathrm{H}_{2} \mathrm{O} / 5 \%{ }^{2} \mathrm{H}_{2} \mathrm{O}$ containing $10 \mathrm{mM}$ sodium acetate, $150 \mathrm{mM} \mathrm{NaCl}$, and $0.02 \%$ (w/v) sodium azide at pH 5.5 (A) and 6.0 (B). Spectra were recorded at $500 \mathrm{MHz}$ and $37^{\circ} \mathrm{C}$. (C) Ribbon view of IGF-I (PDB 1PMX) (62) showing the side chains of Arg36, Arg37, and Ala38. B, C, A, and D domains of the IGF-I molecule are colored pink, blue, green, and orange, respectively. Disulfide bonds are colored yellow. 
Table S1. Summary of the IGF-I crystal structures used in comparison in Figure 6

\begin{tabular}{ccccccc}
\hline PDB & Ref & Protein & $\begin{array}{c}\text { Resolution } \\
(\AA)\end{array}$ & R-Free & Space group & Mean B-factors \\
& & & & & Phe49/49-54/A1l \\
\hline 1GZR & $(42)$ & IGF-I & 2.00 & 0.295 & C222 ${ }_{1}$ & $22.9 / 26.4 / 27.5$ \\
1 IMX & $(41)$ & IGF-I & 1.82 & 0.258 & C222 1 & $28.9 / 30.0 / 33.8$ \\
1 H59 & $(20)$ & IGF-I·mini-N-BP-5 & 2.10 & 0.262 & P2 ${ }_{1} 3$ & $32.2 / 35.5 / 33.8$ \\
2DSR & $(23)$ & IGF-I·N-BP-4·C-BP-4 & 2.10 & 0.256 & C2(C121) & $13.5 / 16.2 / 16.6$ \\
\hline
\end{tabular}


Table S2. Summary of NMR experiments described in the text and major effects observed

\begin{tabular}{|c|c|c|c|c|}
\hline \multirow[t]{2}{*}{ Observable } & \multicolumn{3}{|c|}{ Additive } & \multirow[t]{2}{*}{ Major effects } \\
\hline & N-BP-2 & C-BP-2 & Heparin & \\
\hline${ }^{15} \mathrm{~N} /{ }^{13} \mathrm{C}-\mathrm{IGF}-\mathrm{I}$ & & + & & Peak broadening \\
\hline${ }^{15} \mathrm{~N} /{ }^{13} \mathrm{C}-\mathrm{IGF}-\mathrm{I}$ & + & & & Peak shift \\
\hline${ }^{15} \mathrm{~N} /{ }^{13} \mathrm{C}-\mathrm{IGF}-\mathrm{I}$ & + & + & & Peak shift \\
\hline${ }^{15} \mathrm{~N} /{ }^{13} \mathrm{C}-\mathrm{IGF}-\mathrm{I}$ & + & + & + & Peak shift plus broadening \\
\hline${ }^{15} \mathrm{~N} /{ }^{13} \mathrm{C}-\mathrm{IGF}-\mathrm{I}$ & & & + & Peak shift \\
\hline${ }^{15} \mathrm{~N}-\mathrm{N}-\mathrm{BP}-2$ & & + & & Peak shift plus broadening \\
\hline${ }^{15} \mathrm{~N}-\mathrm{C}-\mathrm{BP}-2$ & + & & & Peak shift plus broadening \\
\hline
\end{tabular}

